\title{
Article \\ Peroxidase-Like Metal-Based Nanozymes: Synthesis, Catalytic Properties, and Analytical Application
}

\author{
Olha Demkiv ${ }^{1,2}{ }^{2}$ Nataliya Stasyuk ${ }^{1}$, Roman Serkiz ${ }^{1}\left(\mathbb{D}\right.$, Galina Gayda ${ }^{1, *}\left(\mathbb{D}\right.$, Marina Nisnevitch ${ }^{3, *}$ \\ and Mykhailo Gonchar ${ }^{1,4}$ \\ 1 Institute of Cell Biology, National Academy of Sciences of Ukraine, 79005 Lviv, Ukraine; \\ demkivo@nas.gov.ua (O.D.); stasukne@nas.gov.ua (N.S.); rserkiz@gmail.com (R.S.); \\ gonchar@cellbiol.lviv.ua (M.G.) \\ 2 Faculty of Veterinary Hygiene, Ecology and Law, Stepan Gzhytskyi National University of Veterinary \\ Medicine and Biotechnologies, 79000 Lviv, Ukraine \\ 3 Department of Chemical Engineering, Ariel University, Kyriat-ha-Mada, Ariel 4070000, Israel \\ 4 Department of Biology and Chemistry, Drohobych Ivan Franko State Pedagogical University, \\ 82100 Drohobych, Ukraine \\ * Correspondence: galina.gayda@gmail.com or galina.gayda@nas.gov.ua (G.G.); marinan@ariel.ac.il (M.N.); \\ Tel.: +380-226-2144 (G.G.); +972-3914-3042 (M.N.)
}

Citation: Demkiv, O.; Stasyuk, N.; Serkiz, R.; Gayda, G.; Nisnevitch, M.; Gonchar, M. Peroxidase-Like Metal-Based Nanozymes: Synthesis, Catalytic Properties, and Analytical Application. Appl. Sci. 2021, 11, 777. https://doi.org/10.3390/app11020777

Received: 2 December 2020 Accepted: 13 January 2021 Published: 15 January 2021

Publisher's Note: MDPI stays neutral with regard to jurisdictional clai$\mathrm{ms}$ in published maps and institutional affiliations.

Copyright: (C) 2021 by the authors. Licensee MDPI, Basel, Switzerland. This article is an open access article distributed under the terms and conditions of the Creative Commons Attribution (CC BY) license (https:// creativecommons.org/licenses/by/ $4.0 /)$.

\begin{abstract}
Nanozymes (NZs) are nanostructured artificial enzymes that mimic catalytic properties of natural enzymes. The NZs have essential advantages over natural enzymes, namely low preparation costs, stability, high surface area, self-assembling capability, size and composition-dependent activities, broad possibility for modification, and biocompatibility. NZs have wide potential practical applications as catalysts in biosensorics, fuel-cell technology, environmental biotechnology, and medicine. Most known NZs are mimetics of oxidoreductases or hydrolases. The present work aimed to obtain effective artificial peroxidase (PO)-like NZs (nanoPOs), to characterize them, and to estimate the prospects of their analytical application. NanoPOs were synthesized using a number of nanoparticles (NPs) of transition and noble metals and were screened for their catalytic activity in solution and on electrodes. The most effective nanoPOs were chosen as NZs and characterized by their catalytic activity. Kinetic parameters, size, and structure of the best nanoPOs $\left(\mathrm{Cu} / \mathrm{Ce}^{\mathrm{S}}\right)$ were determined. $\mathrm{Cu} / \mathrm{Ce}^{\mathrm{S}}$-based sensor for $\mathrm{H}_{2} \mathrm{O}_{2}$ determination showed high sensitivity $\left(1890 \mathrm{~A} \cdot \mathrm{M}^{-1} \cdot \mathrm{m}^{-2}\right)$ and broad linear range $(1.5-20,000 \mu \mathrm{M})$. The possibility to apply $\mathrm{Cu} / \mathrm{Ce}^{\mathrm{S}}-\mathrm{NZ}$ as a selective layer in an amperometric sensor for hydrogen-peroxide analysis of commercial disinfectant samples was demonstrated.
\end{abstract}

Keywords: nanozyme; nano-peroxidase; synthesis; catalytic properties; amperometric sensors; hydrogen peroxide; disinfectant analysis

\section{Introduction}

Peroxidase (PO; E.C. 1.11.1.7) is the oxidoreductase that catalyzes oxidation of organic substrates in the presence of hydrogen peroxide $\left(\mathrm{H}_{2} \mathrm{O}_{2}\right)$ as an electron acceptor. The

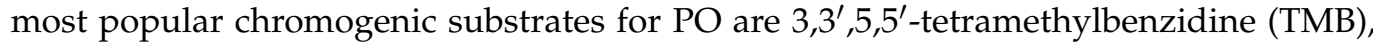
2,2'-azinobis [3-ethylbenzothiazoline-6-sulfonic acid] (ABTS), and o-phenylenediamine (OPD). In the active site PO contains heme, an iron-porphyrin derivative [1]. The POmediated catalytic process occurs via a peroxidative cycle. During the PO-induced substrate oxidation in the presence of $\mathrm{H}_{2} \mathrm{O}_{2}$, the central iron is switched between the ferric(III) and intermediate ferryl(IV) states. The latter intermediate compound exhibits extremely high oxidative activity $[2,3]$.

$\mathrm{PO}$ is widely used in different fields of science and industry, especially in analytics for $\mathrm{H}_{2} \mathrm{O}_{2}$ determination [1]. Many natural enzymes (oxidases) produce $\mathrm{H}_{2} \mathrm{O}_{2}$ as a byproduct of their enzymatic reactions, so that detection of the target substrates can be performed by 
measuring the generation of $\mathrm{H}_{2} \mathrm{O}_{2}$. This principle is widely used in oxidase/peroxidasebased biosensors [4,5]. To determine $\mathrm{H}_{2} \mathrm{O}_{2}$, PO-catalyzed decomposition of $\mathrm{H}_{2} \mathrm{O}_{2}$ may be detected with optical biosensors (in the presence of chromogenic substrates) or with amperometric biosensors. The wide practical application of natural PO is still limited, however, due to the high cost of the enzyme and fast enzyme inactivation in the presence of $\mathrm{H}_{2} \mathrm{O}_{2}$.

Artificial enzymes having PO activity, especially PO-like nanozymes (NZs) or "nanoperoxidases" (nanoPOs), are promising substitutes for natural PO, especially in biosensors [5-11]. Detailed information about NZs, including their definition, history, classification, advantages over natural enzymes, methods of obtaining them, and prospects for practical use, can be found in our recent review [12].

The catalytic properties of NZs strongly depend on the method of synthesis [12-14], chemical structure, particle size, shape, and surface morphology, which can be affected by electrical charge, coating type, doping, loading, and external fields [14-27]. The catalytic performance and efficiency of NZs are usually characterized by kinetic parameters $\left(K_{M}\right.$, $V_{\text {max }}, k_{\text {cat }}, k_{\text {cat }} / K_{M}$ ratio, $\left.\mathrm{IC}_{50}\right)$ and morphological characteristics [7]. In most cases, the catalytic efficiency of NZs is lower compared to natural analogues, but some NZs can compete with natural enzymes [5-7,19].

Nanoperoxidases can be prepared in different ways, such as sol-gel, hydrothermal and solvothermal methods, electrodeposition, chemical reduction, green synthesis, pyrolysis, polymerization, polycondensation, coprecipitation, laser dewetting, and others [7,12]. For ultrafast preparation of NZs containing metal oxides of transition metals, such as $\mathrm{ZnCo}_{2} \mathrm{O}_{4}, \mathrm{NiCO}_{2} \mathrm{O}_{4}, \mathrm{MnCo}_{2} \mathrm{O}_{4}, \mathrm{NiMn}_{2} \mathrm{O}_{4}, \mathrm{CoCu}_{2} \mathrm{O}_{4}$, and $\mathrm{Co}_{3} \mathrm{O}_{4}$, a new synthetic method was proposed using basic deep eutectic solvents. In this method, the designed solvents act simultaneously as a solvent, a shape-control agent and a reactant [28].

Each method of NZ synthesis has advantages and drawbacks [7,12,13]. The chemical reduction method is the most popular due to its rapidity and simplicity. The morphology and particle-size distribution of the chemically synthesized NZs may be controlled by changing molar concentration of compounds, the type of reductant, and the temperature of the reaction [29]. The faster the synthetic process is carried out, the smaller the sizes of obtained NZs, and vice versa [30]. To obtain NZs of higher purity and stronger stoichiometric control, the coprecipitation method must be chosen [31].

A number of new low-cost PO-like NZs having high catalytic activity have been described and used for the development of effective $\mathrm{H}_{2} \mathrm{O}_{2}$-sensitive sensors [32-35]. These sensors may serve as prospective platforms in the construction of different oxidase-based biosensors for quantitative detection of different biomarkers. Biosensors with PO-like NZs can be applied in clinical diagnostics, theranostics, therapy control, and cell/tissue growth and proliferation [35-40].

In our previous studies, we demonstrated the possibility of developing reagentless amperometric biosensors using PO-like NZs. The NZs were synthesized by different methods, including electrodeposition, chemical synthesis, and green synthesis [41,42]. The most effective PO-like NZs, PtRu and hexacyanoferrate (HCF) of copper (CuHCF), were shown to be promising catalysts in amperometric (bio)sensors. When immobilized on graphite electrodes (GEs), PtRu and CuHCF were used for $\mathrm{H}_{2} \mathrm{O}_{2}$ analysis of a sample of commercial disinfectant, and for construction of oxidase-based amperometric biosensors for the determination of ethanol, methyl amine [41], and glucose [42].

Nanozymes having high mimic enzyme activities are very prospective for analytical purposes, particularly, for clinic diagnosis [6,12,13]. Most commercial diagnostic kits and biosensors use natural enzymes selective for metabolites, e.g., different oxidases and peroxidase. The latter enzyme is especially important for ELISA tests, which are very often used in clinic, food control, and sport medicine [1-5]. For this reason, synthesis of new materials capable to mimic peroxidase activity is a very important challenge for modern nanotechnology. 
The aim of this work was to obtain effective NZs having PO-like activity, to characterize these nanoperoxidase NZs (nanoPOs), and to estimate the prospects of their analytical application.

The novelty of the current research is a synthesis of a broad row of hybrid metal nanoparticles (NPs) containing transition and noble metals, and a comparative study of their catalytic activity when immobilized on electrodes as well as in a solution. The latter issue is almost not related to in literature. Kinetic parameters, size, and structure of the most effective nanoPOs were determined. The $\mathrm{Cu} / \mathrm{Ce}$-based sensor for $\mathrm{H}_{2} \mathrm{O}_{2}$ determination showed the highest sensitivity $\left(1890 \mathrm{~A} \cdot \mathrm{M}^{-1} \cdot \mathrm{m}^{-2}\right)$, a broad linear range $(1.5-20,000 \mu \mathrm{M})$, and a high current response $(786 \mu \mathrm{A})$ upon $\mathrm{H}_{2} \mathrm{O}_{2}$ addition. The possibility to apply $\mathrm{Cu} / \mathrm{Ce}^{\mathrm{S}}-\mathrm{NZ}$ as a selective layer in an amperometric sensor for hydrogen peroxide analysis in commercial disinfectant samples was demonstrated.

\section{Materials and Methods}

\subsection{Reagents}

Ascorbic acid, $\mathrm{Ce}\left(\mathrm{HCO}_{3}\right)_{4}, \mathrm{AgNO}_{3}$, chloroplatinic acid $\left(\mathrm{H}_{2} \mathrm{PtCl}_{6}\right), \mathrm{HAuCl}_{4}$, copper(II) sulfate $\left(\mathrm{CuSO}_{4}\right)$, zinc(II) sulfate $\left(\mathrm{ZnSO}_{4}\right), o$-dianisidine, hydrogen peroxide $\left(\mathrm{H}_{2} \mathrm{O}_{2}\right.$, $30 \%$ ), iron(III) chloride $\left(\mathrm{FeCl}_{3} \times 4 \mathrm{H}_{2} \mathrm{O}\right)$, palladium chloride $\left(\mathrm{PdCl}_{3}\right)$, sodium borohydride $\left(\mathrm{NaBH}_{4}\right)$, Nafion (5\% solution in $90 \%$ low-chain aliphatic alcohols), and all other reagents and solvents used in this work were purchased from Sigma-Aldrich (Steinheim, Germany). All reagents were of analytical grade and were used without further purification. All solutions were prepared using ultrapure water obtained with the Milli-Q ${ }^{\circledR}$ IQ 7000 Water Purification system (Merck KGaA, Darmstadt, Germany).

\subsection{Synthesis of NPS}

NPs were synthesized by the reduction of metal ions from appropriate salts, according to the methods used in our modifications [41-44]. The conditions of NP synthesis are presented in Table 1. NPs were collected by centrifugation under $10,000 \times g$ for 40 min (Hettich Micro-22R centrifuge), washed twice with water, and precipitated by centrifugation. Pellets were suspended in $0.2 \mathrm{~mL}$ of water and stored until use at $+4{ }^{\circ} \mathrm{C}$.

Table 1. Methods of chemical synthesis of nanoparticles.

\begin{tabular}{|c|c|c|}
\hline No & NPs & Reaction Mixture and Conditions \\
\hline 1 & $\mathrm{Fe} / \mathrm{Ce}^{\mathrm{S}}$ & 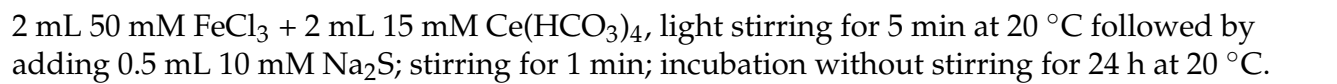 \\
\hline 2 & $\mathrm{Cu} / \mathrm{Ce}^{\mathrm{s}}$ & $\begin{array}{l}1 \mathrm{~mL} 0.01 \mathrm{mM} \mathrm{Ce}\left(\mathrm{HCO}_{3}\right)_{4}+1 \mathrm{~mL} 10 \mathrm{mM} \text { sodium borohydride, vigorous stirring for } 5 \mathrm{~min} \\
\text { followed by adding } 2 \mathrm{~mL} 20 \mathrm{mM} \mathrm{CuSO}_{4} \text {; incubation without stirring for } 1 \mathrm{~h} \text { at } 20^{\circ} \mathrm{C}+0.1 \mathrm{~mL} \\
10 \mathrm{mM} \mathrm{Na} 2 \mathrm{~S} \text {; stirring for } 5 \mathrm{~min} \text { at } 20^{\circ} \mathrm{C} \text {. }\end{array}$ \\
\hline 3 & $\mathrm{Fe} / \mathrm{Mn}$ & $\begin{array}{l}2 \mathrm{~mL} 50 \mathrm{mM} \mathrm{FeCl}_{3}+2 \mathrm{~mL} 50 \mathrm{mM} \mathrm{MnSO} \text {, light stirring for } 5 \mathrm{~min} \text { at } 20{ }^{\circ} \mathrm{C} \text { followed by adding } \\
0.5 \mathrm{~mL} 10 \mathrm{mM} \mathrm{Na}_{2} \mathrm{~S} \text {; stirring for } 1 \mathrm{~min} \text {; incubation without stirring for } 24 \mathrm{~h} \text { at } 20^{\circ} \mathrm{C} \text {. }\end{array}$ \\
\hline 4 & $\mathrm{Ag} / \mathrm{Ce}^{\mathrm{S}}$ & $\begin{array}{l}2 \mathrm{~mL} 50 \mathrm{mM} \mathrm{AgNO}_{3}+2 \mathrm{~mL} 15 \mathrm{mM} \mathrm{Ce}\left(\mathrm{HCO}_{3}\right)_{4} \text {, light stirring for } 5 \mathrm{~min} \text { followed by adding } \\
0.1 \mathrm{~mL} 10 \mathrm{mM} \mathrm{Na}_{2} \mathrm{~S} \text {; stirring for } 1 \mathrm{~min} \text { at } 20^{\circ} \mathrm{C} \text {. incubation without stirring for } 24 \mathrm{~h} \text { at } 20^{\circ} \mathrm{C} \text {. }\end{array}$ \\
\hline 5 & $\mathrm{Pt} / \mathrm{Cu}$ & $\begin{array}{l}0.2 \mathrm{~mL} 48 \mathrm{mM} \mathrm{H}_{2} \mathrm{PtCl}_{6}+0.16 \mathrm{~mL} 100 \mathrm{mM} \text { ascorbic acid, vigorous stirring for } 5 \mathrm{~min} \text { followed by } \\
\text { adding } 1 \mathrm{~mL} 100 \mathrm{mM} \mathrm{CuSO}_{4} \text { and } 0.2 \mathrm{~mL} 100 \mathrm{mM} \text { ascorbic acid; incubation without stirring for } \\
24 \mathrm{~h} \text { at } 20^{\circ} \mathrm{C} \text {. }\end{array}$ \\
\hline 6 & $\mathrm{Fe} / \mathrm{Ce}$ & 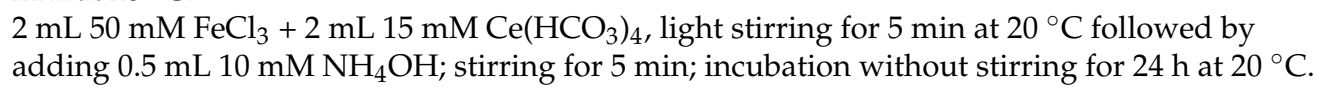 \\
\hline 7 & $\mathrm{Zn} / \mathrm{Ce}$ & $\begin{array}{l}2 \mathrm{~mL} 50 \mathrm{mM} \mathrm{ZnSO} \mathrm{m}_{4}+2 \mathrm{~mL} 15 \mathrm{mM} \mathrm{Ce}\left(\mathrm{HCO}_{3}\right)_{4} \text {, light stirring for } 5 \mathrm{~min} \text { at } 20{ }^{\circ} \mathrm{C} \text { followed by } \\
\text { adding } 0.5 \mathrm{~mL} 10 \mathrm{mM} \mathrm{NH} \mathrm{mH}_{4} \mathrm{OH} \text {; stirring for } 5 \mathrm{~min} \text {; incubation without stirring for } 24 \mathrm{~h} \text { at } 20^{\circ} \mathrm{C} \text {. }\end{array}$ \\
\hline 8 & $\mathrm{Cu} / \mathrm{Ce}$ & $\begin{array}{l}2 \mathrm{~mL} 50 \mathrm{mM} \mathrm{CuSO}_{4}+2 \mathrm{~mL} 15 \mathrm{mM} \mathrm{Ce}\left(\mathrm{HCO}_{3}\right)_{4} \text {, light stirring for } 5 \mathrm{~min} \text { at } 20{ }^{\circ} \mathrm{C} \text { followed by } \\
\text { adding } 0.5 \mathrm{~mL} 10 \mathrm{mM} \mathrm{NH} \mathrm{OH}_{4} \mathrm{OH} \text {; stirring for } 5 \mathrm{~min} \text {; incubation without stirring for } 24 \mathrm{~h} \text { at } 20^{\circ} \mathrm{C} \text {. }\end{array}$ \\
\hline 9 & $\mathrm{Pd} / \mathrm{Ce}$ & 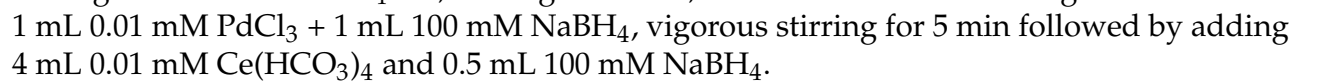 \\
\hline 10 & $\mathrm{Pd} / \mathrm{Cu}$ & 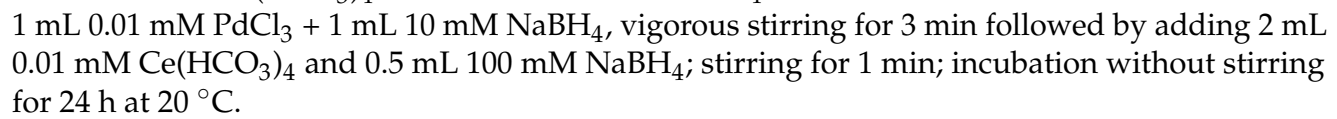 \\
\hline
\end{tabular}


Table 1. Cont.

\begin{tabular}{|c|c|c|}
\hline No & NPs & Reaction Mixture and Conditions \\
\hline 11 & $\mathrm{Ag} / \mathrm{Ce}$ & $\begin{array}{l}2 \mathrm{~mL} 50 \mathrm{mM} \mathrm{AgNO} 3+2 \mathrm{~mL}_{3} \mathrm{mM} \mathrm{Ce}\left(\mathrm{HCO}_{3}\right)_{4} \text {, vigorous stirring for } 5 \mathrm{~min} \text { at } 20{ }^{\circ} \mathrm{C} \text { followed by } \\
\text { adding } 0.1 \mathrm{~mL} 100 \mathrm{mM} \mathrm{NaBH}_{4} \text {; stirring for } 5 \mathrm{~min} \text {; incubation without stirring for } 24 \mathrm{~h} \text { at } 20^{\circ} \mathrm{C} \text {. }\end{array}$ \\
\hline 12 & $\mathrm{Au} / \mathrm{Cu}$ & 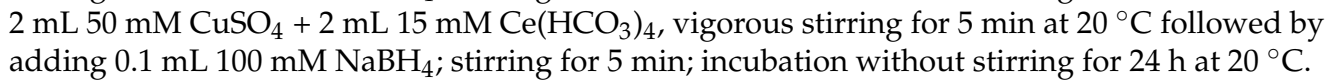 \\
\hline 13 & $\mathrm{Au}$ & $\begin{array}{l}0.145 \mathrm{~mL} 58.5 \mathrm{mM} \mathrm{HAuCl}_{4}+10 \mathrm{~mL} 10 \mathrm{mM} \mathrm{CTAB} \text {, vigorous stirring; + } 0.18 \mathrm{~mL} 100 \mathrm{mM} \mathrm{NaBH}_{4} ; \\
\text { stirring for } 2 \mathrm{~h} \text { at } 20^{\circ} \mathrm{C} \text {. }\end{array}$ \\
\hline 14 & $\mathrm{Ag} / \mathrm{Cu}$ & 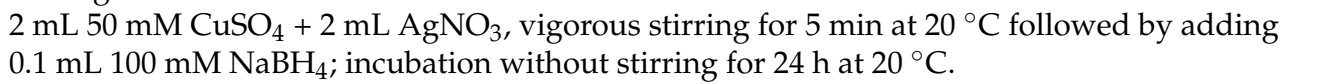 \\
\hline 15 & $\mathrm{Pt} / \mathrm{Ag}$ & $\begin{array}{l}0.2 \mathrm{~mL}_{4} \mathrm{mM} \mathrm{H}_{2} \mathrm{PtCl}_{6}+2 \mathrm{~mL} \mathrm{AgNO} \text {, vigorous stirring for } 5 \mathrm{~min} \text { at } 20{ }^{\circ} \mathrm{C} \text { followed by adding } \\
0.1 \mathrm{~mL} 100 \mathrm{mM} \mathrm{NaBH}_{4} ; \text { stirring for } 5 \mathrm{~min} \text {; incubation without stirring for } 24 \mathrm{~h} \text { at } 20{ }^{\circ} \mathrm{C} \text {. }\end{array}$ \\
\hline 16 & $\mathrm{Ag} / \mathrm{Zn}$ & 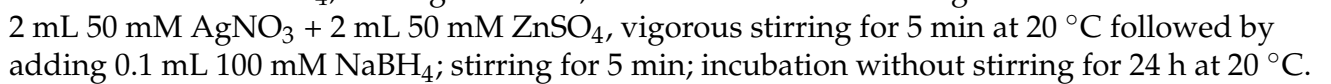 \\
\hline
\end{tabular}

\subsection{Morphological Analysis of NPs Using Scanning Electron Microscopy (SEM)}

Morphological analyses of the samples were performed using a SEM microanalyzer (REMMA-102-02, Sumy, Ukraine). The samples in different dilutions $(2 \mu \mathrm{L})$ were dropped onto the surface of a silicon wafer and were dried at room temperature. The distance from the last lens of the microscope to the sample (WD) ranged from $17.1 \mathrm{mM}$ to $21.7 \mathrm{mM}$. The accelerator voltage was in the range of 20 to $40 \mathrm{eV}$.

\subsection{Determination of Peroxidase-Like Activity of NPs in Solution}

PO-like activity of the NPs was measured by the colorimetric method, with $o$-dianisidine as a chromogenic substrate in the presence of $\mathrm{H}_{2} \mathrm{O}_{2}$. The generated color was determined at $525 \mathrm{~nm}$ using a Shimadzu UV1650 PC spectrophotometer (Kyoto, Japan). One unit (U) of PO-like activity was defined as the amount of NZ releasing $1 \mu \mathrm{MoL} \mathrm{H}_{2} \mathrm{O}_{2}$ per $1 \mathrm{~min}$ at $30^{\circ} \mathrm{C}$ under standard assay conditions.

The procedure of the PO-like activity assay: $10 \mu \mathrm{L}$ of the aqueous suspension of NPs $(1 \mathrm{mg} / \mathrm{mL})$ was incubated in a glass tube with $1 \mathrm{~mL}$ of $0.17 \mathrm{mM}$ o-dianisidine in $50 \mathrm{mM} \mathrm{NaOAc}$ buffer, $\mathrm{pH} 4.5$ (as a control); and with the same substrate in the presence of $8.8 \mathrm{mM} \mathrm{H}_{2} \mathrm{O}_{2}$ (as a substrate for PO). Addition of NPs to the substrate stimulated the development of an orange color over time, indicating an enzymatic reaction. The enzymemimetic activity could be assessed qualitatively with the naked eye and was measured quantitatively with a spectrophotometer. After incubation for an exact time (1-10 $\mathrm{min})$ at $30{ }^{\circ} \mathrm{C}$, and upon appearance of the orange color, the reaction was stopped by the addition of $0.26 \mathrm{~mL} 12 \mathrm{M} \mathrm{HCl}$. The millimolar extinction coefficient of the resulting pink dye in the acidic solution was $13.38 \mathrm{mM}^{-1} \cdot \mathrm{cm}^{-1}$.

\subsection{Sensor Evaluation}

2.5.1. Apparatus, Measurements, and Statistical Analysis

The amperometric sensors were evaluated using constant-potential amperometry in a three-electrode configuration with an $\mathrm{Ag} / \mathrm{AgCl} / \mathrm{KCl}(3 \mathrm{M})$ reference electrode, a Ptwire counter electrode, and a graphite working electrode. Graphite rods (type RW001, $3.05 \mathrm{mM}$ diameter) from Ringsdorff Werke (Bonn, Germany) were sealed in glass tubes using epoxy glue to form disk electrodes. Before sensor preparation, the graphite electrode (GE) was polished with emery paper and a polishing cloth using decreasing particle sizes of alumina paste (Leco, Germany). The polished electrodes were rinsed with water in an ultrasonic bath.

Amperometric measurements were carried out using a CHI 1200A potentiostat (IJ Cambria Scientific, Burry Port, UK) connected to a personal computer and performed in a batch mode under continuous stirring in an electrochemical cell with a $20 \mathrm{~mL}$ volume at $25^{\circ} \mathrm{C}$. 
All the experiments were carried out in triplicate trials. Analytical characteristics of the electrodes were statistically processed using OriginPro 8.5 software. The error bars represent the standard error derived from three independent measurements. Calculation of the apparent Michaelis-Menten constants $\left(K_{M}^{a p p}\right)$ was performed automatically by this program according to the Lineweaver-Burk equation.

2.5.2. Immobilization of Metallic NPs onto Electrodes, Testing Their Electro- and PO-Like Activity

For construction of the NZ-based electrode, $5 \mu \mathrm{L}$ of NP suspension $(1 \mathrm{mg} / \mathrm{mL})$ was dropped onto the surfaces of GEs. After drying for $10 \mathrm{~min}$ at room temperature, the layer of NPs on the electrodes was covered with $5 \mu \mathrm{L}$ Nafion membrane. The electrodes were washed with corresponding buffer solutions before and after each measurement.

The electrochemical properties of the synthesized NPs were studied by cyclic voltammetry $(\mathrm{CV})$ on the GEs in the range from -1000 to $+1000 \mathrm{mV}$ with the scan rate of $50 \mathrm{mV} \mathrm{min}^{-1}$; the profiles of amperometric signals in increasing concentrations of $\mathrm{H}_{2} \mathrm{O}_{2}$ were compared. The most electroactive NPs, which had the highest PO-like properties, were chosen for further investigation.

\section{Results and Discussion}

\subsection{Obtaining and Characterizing the Best Peroxidase-Like Nanozymes}

First, different NPs were synthesized and screened for their reaction to $\mathrm{H}_{2} \mathrm{O}_{2}$ in solution. PO-like activities were measured with $o$-dianisidine as the chromogenic substrate. The experiments demonstrated that the synthesized NPs, especially $\mathrm{Au} / \mathrm{Cu}, \mathrm{Ag} / \mathrm{Ce}^{\mathrm{S}}$, $\mathrm{Fe} / \mathrm{Ce}^{\mathrm{S}}$, and $\mathrm{Zn} / \mathrm{Ce}$, possessed significant PO-like activities in solution (Table 2). These results are in agreement with the data of other researchers $[9,10]$.

Table 2. Peroxidase (PO)-like activities of the synthesized nanozymes NZs in solution.

\begin{tabular}{cccc}
\hline No. & Nanozyme & Synthesis Method & Specific Activity, Units /mg \\
\hline 1 & $\mathrm{Fe} / \mathrm{Ce} \mathrm{S}$ & $\mathrm{Na}_{2} \mathrm{~S}$ & $1.86 \pm 0.16$ \\
2 & $\mathrm{Cu} / \mathrm{Ce}$ & $\mathrm{NaBH}_{4} / \mathrm{Na}_{2} \mathrm{~S}$ & $1.27 \pm 0.11$ \\
3 & $\mathrm{Fe} / \mathrm{Mn}$ & $\mathrm{Na}_{2} \mathrm{~S}$ & $0.12 \pm 0.01$ \\
4 & $\mathrm{Ng} / \mathrm{Ce}$ & $\mathrm{Na}_{2} \mathrm{~S}$ & $0.05 \pm 0.004$ \\
5 & $\mathrm{Pt} / \mathrm{Cu}$ & $\mathrm{Ascorbic}^{\mathrm{S}}$ & $1.84 \pm 0.14$ \\
6 & $\mathrm{Fe} / \mathrm{Ce}$ & $\mathrm{NH}_{4} \mathrm{OH}$ & $3.06 \pm 0.26$ \\
7 & $\mathrm{Nn} / \mathrm{Ce}$ & $\mathrm{NH}_{4} \mathrm{OH}$ & $2.28 \pm 0.21$ \\
8 & $\mathrm{NH} \mathrm{OHH}_{4}$ & $0.90 \pm 0.007$ \\
9 & $\mathrm{NaBH}$ & $0.72 \pm 0.06$ \\
10 & $\mathrm{Nd} / \mathrm{Ce}$ & $\mathrm{NaBH}_{4}$ & $0.4 \pm 0.03$ \\
11 & $\mathrm{Pd} / \mathrm{Cu}$ & $\mathrm{NaBH}_{4}$ & $2.50 \pm 0.22$ \\
12 & $\mathrm{Ng} / \mathrm{Ce}$ & $\mathrm{NaBH}_{4}$ & $4.22 \pm 0.34$ \\
13 & $\mathrm{Nu} / \mathrm{Cu}$ & $\mathrm{NaBH}_{4}$ & $2.62 \pm 0.19$ \\
14 & $\mathrm{Nu}$ & $\mathrm{NaBH}_{4}$ & $0.24 \pm 0.02$ \\
15 & $\mathrm{Ng} / \mathrm{Cu}$ & $\mathrm{NaBH}_{4}$ & $1.40 \pm 0.11$ \\
16 & $\mathrm{NaBH}$ & $0.79 \pm 0.06$ \\
\hline
\end{tabular}

S_NPs obtained by a sulfide method.

The most catalytically active NZs were characterized by SEM coupled with X-ray microanalysis (SEM-XRM). SEM provided information on the size, distribution, and shape of the tested sample. Figure S1 presents the overall morphology of the formed hybrid particles. The XRM images of the synthesized NZs showed the characteristic peaks for metals of the composites.

The obtained Pd/Ce NPs have the shape of a sphere with a diameter of approximately $200 \mathrm{~nm}$. The size of synthesized Pt/Cu NPs is near $500 \mathrm{~nm}$. XRM data for Pt/Cu NPs proved the presence of $\mathrm{Pt}^{0}$ and $\mathrm{Cu}^{0}$ forms, with characteristic peaks $\mathrm{K} \alpha$ at $2.4 \mathrm{keV}$ and $1.4 \mathrm{keV}$, respectively (Figure S1). The size of synthesized Pd/Cu NPs is in the range of 
$500 \mathrm{~nm}-1 \mu \mathrm{M}$. The sole peak at $1.8 \mathrm{keV}$ demonstrates the full covering of CuNPs with the PdNPs.

SEM imaging and XRM data proved the formation of needlelike hybrid Fe/Ce and $\mathrm{Au} / \mathrm{Cu}$ micro particles with the size ranging from 10 to $20 \mu \mathrm{M}$ (Figure S1). The XRM image of $\mathrm{Au} / \mathrm{Cu}$ NPs shows the $\mathrm{K} \alpha$ peaks of $\mathrm{Cu}^{0}$ and $\mathrm{Au}^{0}$, confirming the presence of both CuNPs and AuNPs. It was shown that the Fe/Ce and $\mathrm{Au} / \mathrm{Cu}$ NPs tested look like irregular shaped clusters of microfibrillar structures. The best of catalytically active NZs, namely, $\mathrm{Cu} / \mathrm{CeS}, \mathrm{Au} / \mathrm{Cu}, \mathrm{Ag} / \mathrm{Ce}, \mathrm{Fe} / \mathrm{Ce}, \mathrm{Ag} / \mathrm{Zn}, \mathrm{Pd} / \mathrm{Ce}$, and $\mathrm{Pt} / \mathrm{Cu}$ NPs were chosen for further investigation.

\subsection{Development and Characterization of the NZs-Modified Electrodes}

Our next task was to select the most PO-active NPs immobilized on the electrode surface. It is known that modification of an electrode with some metallic NPs can improve the efficiency of an electron transfer, due to an increase in the electrochemically accessible electrode surface area. Numerous NZs/GEs were screened for their ability to decompose hydrogen peroxide. The electrocatalytic activities of the synthesized NZs, while immobilized on the surface of GEs, were tested by CV and chronoamperometry, as described in Section 2.5.2 (Figure 1 and Figure S2).

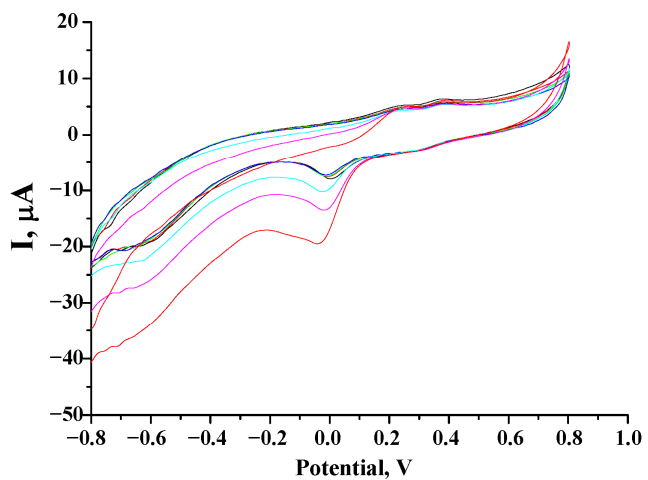

(a)

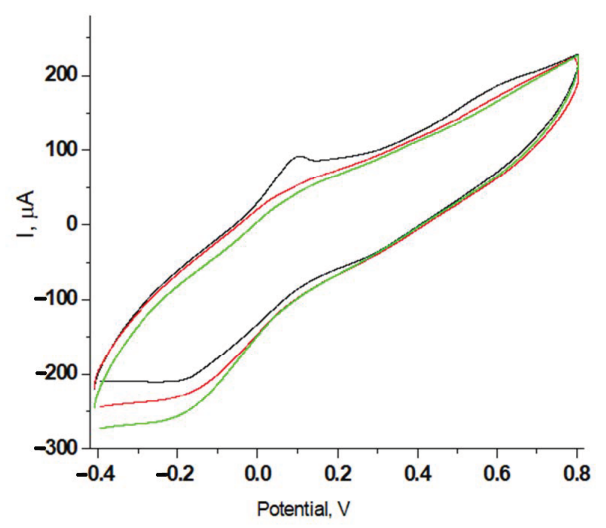

(c)

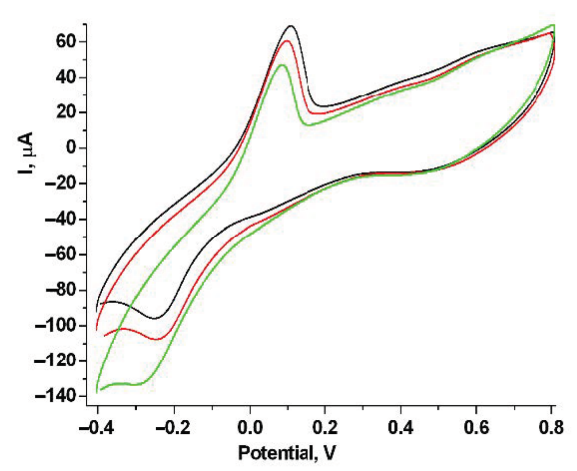

(b)

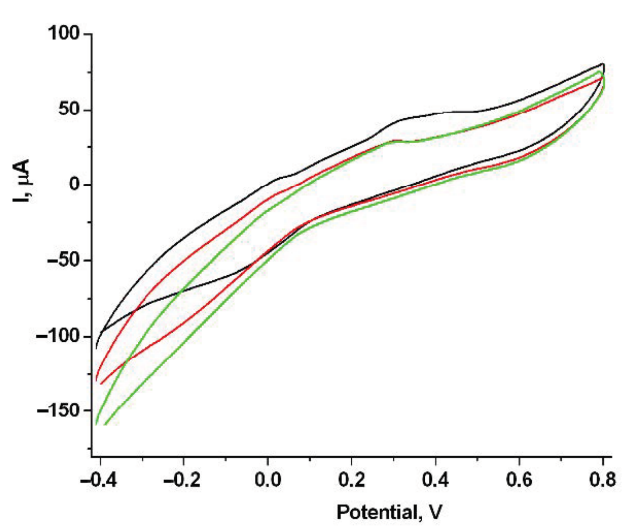

(d)

Figure 1. Cyclic voltammograms (CV) of the graphite electrodes modified with $\mathrm{Cu} / \mathrm{Ce}{ }^{\mathrm{S}}(\mathbf{a}), \mathrm{Fe} / \mathrm{Ce}(\mathbf{b}), \mathrm{Au} / \mathrm{Cu}(\mathbf{c})$, and $\mathrm{Ag} / \mathrm{Ce}(\mathbf{d}) . \mathrm{CV}$ profiles as outputs on addition of $\mathrm{H}_{2} \mathrm{O}_{2}$ in concentration: (a) $-0 \mathrm{mM}$ (blue), $0.2 \mathrm{mM}$ (cyan), $0.5 \mathrm{mM}$ (pink), $1 \mathrm{mM}$ (red); (b-d) $-0 \mathrm{mM}$ (black), $1 \mathrm{mM}$ (red), $3 \mathrm{mM}$ (green). Conditions: scan rate $50 \mathrm{mV} \cdot \mathrm{s}^{-1} ; \mathrm{Ag} / \mathrm{AgCl}$ (reference electrode) in $50 \mathrm{mM} \mathrm{NaOAc}$ buffer, $\mathrm{pH}$ 4.5. The surfaces of the graphite electrode (GE) were modified with $1 \mu \mathrm{g}$ (a) or $5 \mu \mathrm{g}$ NZs (b-d) and covered with Nafion.

In our research, the amperometric responses of different NZs/GEs to added portions of $\mathrm{H}_{2} \mathrm{O}_{2}$ were compared under mild conditions at the working potential of $-50 \mathrm{mV}$. This rather low potential was chosen from the CV profiles (Figure 1), since the main drawback 
of many $\mathrm{H}_{2} \mathrm{O}_{2}$-sensitive NZ-based electrochemical sensors is their nonselectivity under high positive (or negative) working potentials. $\mathrm{H}_{2} \mathrm{O}_{2}$ is able to direct the auto-oxidation on electroactive surfaces at a working potential above $+0.4 \mathrm{~V}$, or auto-reduction at $-0.4 \mathrm{~V}$ or less vs. $\mathrm{Ag} / \mathrm{AgCl}$. Moreover, the real samples containing organic compounds may be easily co-oxidized/co-reduced at extreme potentials, which may result in overestimation of the target analytes in the presence of oxygen. To avoid these problems during sensor analysis, it was important to screen new NZs while working at operating potentials close to zero (0) $\mathrm{V}$ vs. $\mathrm{Ag} / \mathrm{AgCl}[12,43-45]$. This requirement is especially relevant for the construction of biosensors and their exploitation for analysis of real samples (food products, biological liquids, etc.). Our previous experiments with natural $\mathrm{PO}$ as a biorecognition element of amperometric biosensors were also carried out at $-50 \mathrm{mV}$ [41-44].

Using the chronoamperograms, calibration curves were plotted for $\mathrm{H}_{2} \mathrm{O}_{2}$ determination by the developed electrodes (Figure S2). The analytical characteristics of the modified GEs, as deduced from the graphs in comparison with natural PO [42-44], are summarized in Table 3. The linear ranges, limits of detection (LOD), and sensitivities of the electrodes modified with nanoPOs were calculated. The limit of blank values (LOB) for NZ was calculated as $0.3 \times$ LOD. The sensitivity of each NZ-modified electrode was measured for an electrode area of $7.30 \mathrm{mM}^{2}$.

Table 3. Analytical characteristics of the most effective NZs as PO-mimetic placed on electrode.

\begin{tabular}{|c|c|c|c|c|c|c|}
\hline Sensitive Film & No. in Table 2 & $\begin{array}{l}\text { Sensitivity, } \\
\text { A }^{-1} \mathbf{m}^{-2}\end{array}$ & $\begin{array}{l}\text { LOD, } \\
\mu \mathrm{M}\end{array}$ & Linear Range, $\mu \mathrm{M}$ & $K_{M}^{a p p}, \mathbf{m M}$ & $I_{\max }, \mu \mathrm{A}$ \\
\hline $\mathrm{PO}$ & & 352 & & 400 & $4.9 \pm 1.1$ & $5.0 \pm 0.2$ \\
\hline $\mathrm{Cu} / \mathrm{Ce}^{\mathrm{s}}$ & 2 & 1890 & $0.42 \pm 0.006$ & $1.5-20,000$ & $43.3 \pm 14.5$ & $786.4 \pm 167.7$ \\
\hline $\mathrm{Fe} / \mathrm{Ce}$ & 6 & 1372 & $2.90 \pm 0.010$ & 50-1000 & $14.4 \pm 1.3$ & $104.5 \pm 3.3$ \\
\hline $\mathrm{Au} / \mathrm{Cu}$ & 12 & 793 & $4.88 \pm 0.010$ & $50-15,000$ & $28.0 \pm 3.2$ & $213.3 \pm 13.1$ \\
\hline $\mathrm{Ag} / \mathrm{Ce}$ & 11 & 782 & $11 \pm 0.009$ & $50-4000$ & $16.4 \pm 2.5$ & $152.54 \pm 8.8$ \\
\hline $\mathrm{Pd} / \mathrm{Cu}$ & 10 & 581 & $39 \pm 1.20$ & $117-14,300$ & $34.7 \pm 2.02$ & $166.2 \pm 6.4$ \\
\hline $\mathrm{Pd} / \mathrm{Ce}$ & 9 & 496 & $4.55 \pm 0.006$ & $17-4100$ & $13.4 \pm 3.2$ & $68.0 \pm 3.2$ \\
\hline $\mathrm{Ag} / \mathrm{Zn}$ & 16 & 375 & $41 \pm 1.50$ & $17-25,000$ & $18.1 \pm 0.4$ & $96.79 \pm 8.56$ \\
\hline $\mathrm{Pt} / \mathrm{Cu}$ & 5 & 163 & $5.54 \pm 0.002$ & $17-25,000$ & $26.8 \pm 5.0$ & $55.2 \pm 5.4$ \\
\hline
\end{tabular}

S_NPs obtained by a sulfide method.

Figure 2 summarizes the data concerning the PO-like properties of the selected NZs, namely, $\mathrm{Cu} / \mathrm{Ce}^{\mathrm{S}}, \mathrm{Au} / \mathrm{Cu}, \mathrm{Ag} / \mathrm{Ce}, \mathrm{Fe} / \mathrm{Ce}, \mathrm{Ag} / \mathrm{Zn}, \mathrm{Pd} / \mathrm{Ce}$, and $\mathrm{Pt} / \mathrm{Cu}$. The results in Table 3 demonstrate that $\mathrm{Cu} / \mathrm{Ce} \mathrm{S}^{\mathrm{G}} \mathrm{GE}$ exhibited the highest sensitivity $\left(1890 \mathrm{~A} \cdot \mathrm{M}^{-1} \cdot \mathrm{m}^{-2}\right)$ and current response $(786 \mu \mathrm{A})$, the lowest $\mathrm{LOD}(0.42 \mu \mathrm{M})$, and a broad linear range $(1.5-20,000 \mu \mathrm{M})$ upon $\mathrm{H}_{2} \mathrm{O}_{2}$ addition. This structure was therefore studied in more detail as the most effective artificial PO immobilized on the electrode.

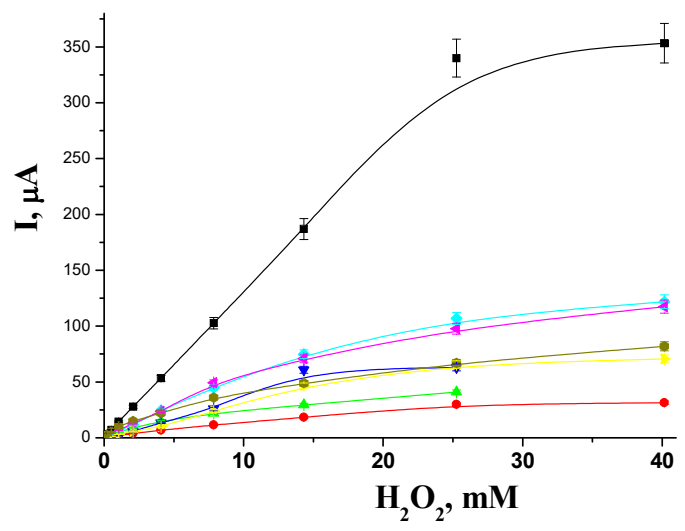

Figure 2. Dependence of the current response on increasing concentrations of $\mathrm{H}_{2} \mathrm{O}_{2}$ for GEs modified with $5 \mu \mathrm{g}$ of different nanozymes: $\mathrm{Cu} / \mathrm{Ce}^{\mathrm{S}}$ (black line), $\mathrm{Au} / \mathrm{Cu}$ (cyan), Ag/Ce (violet), Fe/Ce (khaki), $\mathrm{Ag} / \mathrm{Zn}$ (yellow), Pd/Ce (green), Pt/Cu (red). 


\subsection{Characterization of the Most Effective $\mathrm{Cu} / \mathrm{C} e^{S}$-Modified Electrode}

The $\mathrm{Cu} / \mathrm{Ce}^{\mathrm{S}}$-NZ with the highest $\mathrm{PO}-$ like activity was studied in detail. The $\mathrm{Cu} / \mathrm{Ce}^{\mathrm{S}} / \mathrm{GE}$ demonstrated the highest $\mathrm{PO}$-like activity, compared with other NZs and with natural $\mathrm{PO}$ (Figure S2, Tables 3 and 4). The highest current response $\left(I_{\max }\right)$ on the tested analyte at substrate saturation of the $\mathrm{Cu} / \mathrm{Ce}^{\mathrm{S}} / \mathrm{GE}$ was 157 -fold higher, and its sensitivity was 5.4-fold higher, than that of the PO/GE (Table 3). It is worth mentioning that $\mathrm{Cu} / \mathrm{Ce}^{\mathrm{S}}$ has PO-like ability but lacks oxidase (laccase)-like properties. This conclusion was reached from the results of colorimetric tests using $o$-dianisidine in the presence of $\mathrm{H}_{2} \mathrm{O}_{2}$ as a substrate for $\mathrm{PO}$, and with o-dianisidine only as a substrate for oxidase (sees Section 2.4). The $\mathrm{Cu} / \mathrm{Ce}^{\mathrm{S}}$ specificity to $\mathrm{H}_{2} \mathrm{O}_{2}$ is the important valuable characteristic for applying it as a selective PO-mimetic element in sensors and oxidase-based biosensors. Figure 3 shows the effect of quantity on the NZ immobilized on the GE surface, based on the amperometric signal as a response to $\mathrm{H}_{2} \mathrm{O}_{2}$ addition. Table 4 presents comparative analytical characteristics of the recently developed metallic NZ-based sensors for $\mathrm{H}_{2} \mathrm{O}_{2}$ analysis, including the results described here.

Table 4. The main operational characteristics of the recently described $\mathrm{H}_{2} \mathrm{O}_{2}$-sensitive metallic NZ-based sensors working at low potentials.

\begin{tabular}{|c|c|c|c|c|c|}
\hline Electrode & PO Mimetic & Potential, mV & $\begin{array}{l}\text { Sensitivity, } \\
\text { A }^{-1} \mathbf{m}^{-2}\end{array}$ & $\begin{array}{c}\text { Linear Range, } \\
\mu \mathrm{M}\end{array}$ & Ref. \\
\hline${ }^{1} \mathrm{GCE}$ & $\mathrm{Cu}_{2} \mathrm{O} / \mathrm{PANI} / \mathrm{rGhO}$ & -200 & 394 & $0.8-12,780$ & [45] \\
\hline GCE & $\mathrm{Fe}_{3} \mathrm{O}_{4} / 3 \mathrm{D}$ GNCs & -200 & 2742 & $0.8-330$ & [46] \\
\hline GCE & $\mathrm{Ni}-\mathrm{Fe}$ PBA- $-{ }^{4} \mathrm{HNCs}$ & -50 & 361 & $0.1-20,000$ & [47] \\
\hline GCE & $\begin{array}{c}\text { PB/BG } \\
\text { AuNPs-PB/BG }\end{array}$ & -50 & $\begin{array}{c}2852 \\
11,243\end{array}$ & $\begin{array}{c}4-830 \\
9.2-8100\end{array}$ & [48] \\
\hline${ }^{2} \mathrm{DBD}$ & $\mathrm{PB}$ & & 2100 & & \\
\hline DBD & Ni-FePBA & -50 & 1500 & $0.5-1000$ & [11] \\
\hline GE & $\mathrm{PB} / \mathrm{NZ}$ & & 4500 & & \\
\hline GCE & MnPBA & & 1472 & $3-8610$ & [49] \\
\hline GCE & $\mathrm{rGhO} / \mathrm{Pt}-\mathrm{Ag}$ & -50 & 6996 & $5-1500$ & [50] \\
\hline GCE & $\mathrm{Ni}-\mathrm{PB}$ & -50 & 3500 & $0.1-1000$ & [51] \\
\hline Graphite paste & $\begin{array}{l}\mathrm{Ni}-\mathrm{FePBA} \\
\mathrm{Cu}-\mathrm{FePBA}\end{array}$ & -50 & $\begin{array}{l}1130 \\
2030\end{array}$ & $\begin{array}{c}2-1000 \\
0.5-1000\end{array}$ & {$[52]$} \\
\hline${ }^{3} \mathrm{GE}$ & $\begin{array}{c}\mathrm{PtRu} \\
\mathrm{gCuHCF}\end{array}$ & -50 & $\begin{array}{c}194 \\
1620\end{array}$ & $\begin{array}{c}17-25,000 \\
16-4100\end{array}$ & [41] \\
\hline GE & $\begin{array}{l}\text { gFeHCF } \\
\text { PO }\end{array}$ & -50 & $\begin{array}{c}1090 \\
352\end{array}$ & $\begin{array}{c}116-14,300 \\
15-20,000\end{array}$ & {$[42]$} \\
\hline GCE & Ni-FePBA & 0 & 18,000 & up to 100 & [53] \\
\hline GCE & PNAANI-PB & 0 & 5073 & $1-1000$ & [54] \\
\hline GCE & PB & 50 & 6000 & $0.1-100$ & [55] \\
\hline GCE & $\mathrm{Fe} / \mathrm{rGhO}-\mathrm{Pt}$ & 100 & 3400 & $7.5-4270$ & [56] \\
\hline GCE & $\begin{array}{c}\mathrm{PB} \\
\mathrm{Cu} / \mathrm{Ce}^{\mathrm{S}}\end{array}$ & 180 & $\begin{array}{c}10,000 / 20,000 \\
1890\end{array}$ & $\begin{array}{c}1-5000 \\
1.5-20,000\end{array}$ & [57] \\
\hline GE & $\begin{array}{l}\mathrm{Au} / \mathrm{Cu} \\
\mathrm{Fe} / \mathrm{Ce}\end{array}$ & $\begin{array}{c}-50 \\
-\end{array}$ & $\begin{array}{c}793 \\
1372\end{array}$ & $\begin{array}{l}17-15,000 \\
\text { up to } 1000\end{array}$ & This paper \\
\hline
\end{tabular}

${ }^{1}$ GCE—glassy carbon electrode; ${ }^{2}$ DBD—diamond boron-doped; ${ }^{3}$ GE—graphite electrode; ${ }^{4} \mathrm{HNCs}$-hollow nanocubes. 


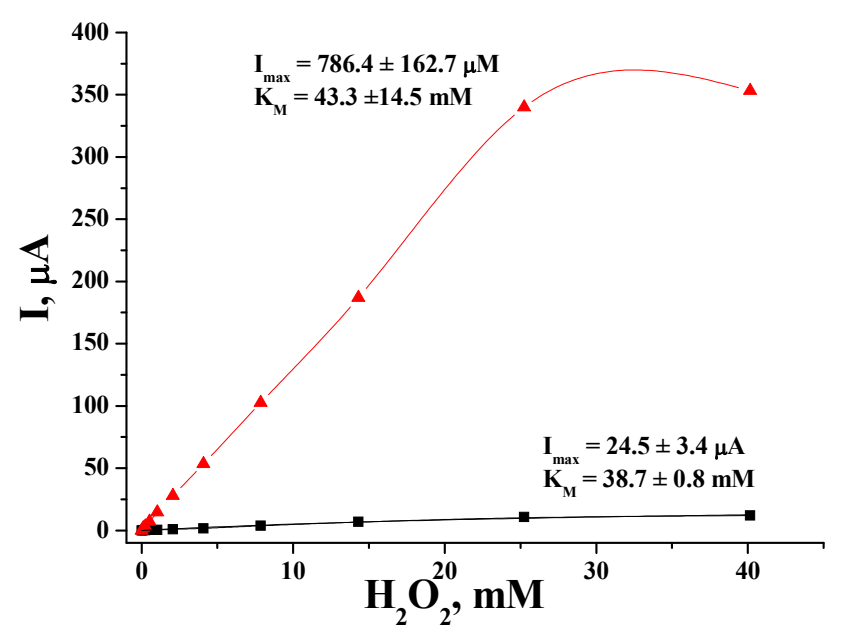

Figure 3. Dependence of the current response on increasing concentrations of $\mathrm{H}_{2} \mathrm{O}_{2}$ for GEs modified with different quantities of $\mathrm{Cu} / \mathrm{Ce}^{\mathrm{S}}: 1 \mu \mathrm{g}$ (black line) and $5 \mu \mathrm{g}$ (red line).

\subsection{Application of $\mathrm{Cu} / \mathrm{Ce} e^{S}$ as a PO-Mimetic in Amperometric Sensors}

To demonstrate the applicability of $\mathrm{Cu} / \mathrm{Ce}^{\mathrm{S}}$ as a chemosensor for $\mathrm{H}_{2} \mathrm{O}_{2}$ detection, analysis of $\mathrm{H}_{2} \mathrm{O}_{2}$ concentration was carried out in samples of commercial products (Figure 4). The disinfectant samples tested were Famidez-Sanosil, Spray Antiseptic for arms and a pharmaceutical solution of $3 \% \mathrm{H}_{2} \mathrm{O}_{2}$. The standard addition test, $\mathrm{SAT}$, approach was used to avoid undesirable effects on analytical results from additives in the tested solutions.

Graphical SAT is a type of quantitative analysis often used in analytical chemistry when a standard is added directly to the aliquots of the analyzed sample. SAT is used in situations where sample components may contribute to the analytical signal, thus making it impossible to use a routine calibration method. Estimation of $\mathrm{H}_{2} \mathrm{O}_{2}$ in the initial sample was performed using the equation $\mathrm{C}=\mathrm{AN} / \mathrm{B}$, where $\mathrm{A}$ and $\mathrm{B}$ are parameters of a linear regression and $\mathrm{N}$ is the dilution factor.

The results of hydrogen peroxide determination in commercial samples in comparison to data of manufacturers are presented in Table 5. The average $\mathrm{H}_{2} \mathrm{O}_{2}$ concentrations determined from the data in Figure 4 correlated well with the manufacturer's data (Table 5), with an error of less than $10 \%$. 


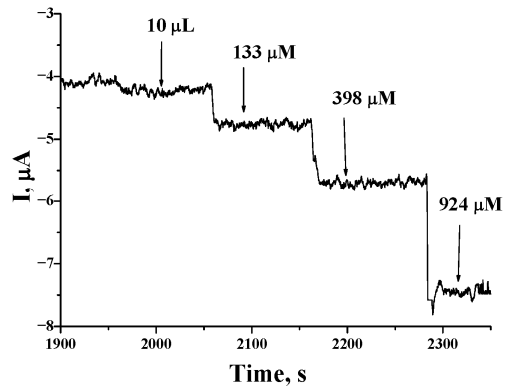

(a)

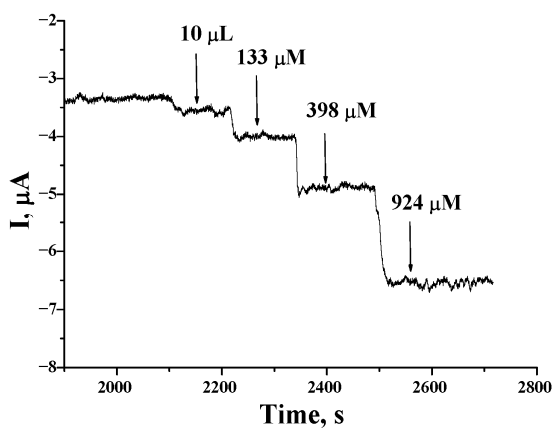

(c)

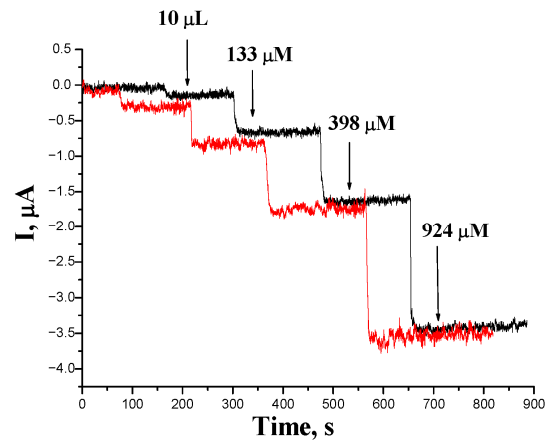

(e)

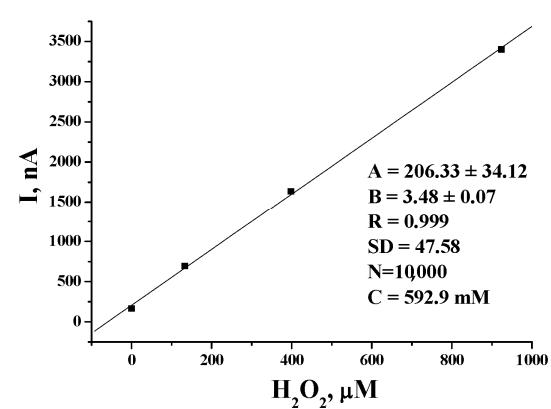

(b)

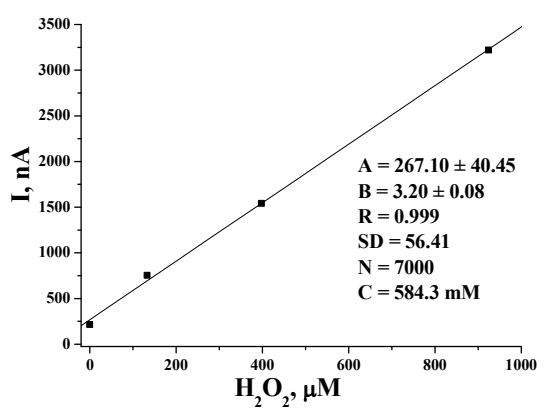

(d)

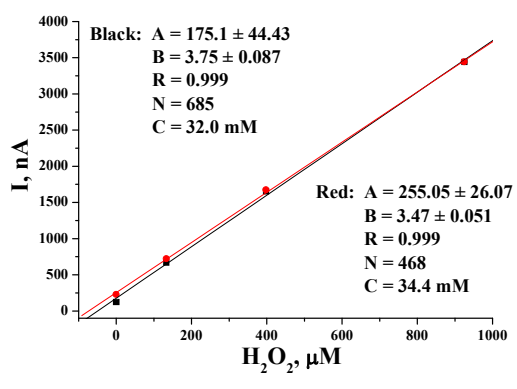

(f)

Figure 4. Analysis of the real samples of disinfectants using $\mathrm{Cu} / \mathrm{Ce}^{\mathrm{S}}$-based chemosensor with the SAT method: chronoamperograms (a,c,e) and correspondent linear graphs (b,d,f). Disinfectants: Famidez-Sanosil (a-d); antiseptic spray (e,f). Analytical conditions: working potential-50 mV vs. $\mathrm{Ag} / \mathrm{AgCl}$ (reference electrode), $50 \mathrm{mM} \mathrm{NaOAc}$ buffer, $\mathrm{pH} 4.5$ at $23^{\circ} \mathrm{C}$.

Table 5. Results of $\mathrm{H}_{2} \mathrm{O}_{2}$ estimation in $\mathrm{H}_{2} \mathrm{O}_{2}$-containing commercial disinfectants.

\begin{tabular}{|c|c|c|c|c|c|}
\hline \multirow{3}{*}{$\begin{array}{l}\text { Commercial } \\
\text { Sample }\end{array}$} & \multicolumn{3}{|c|}{ Concentration of $\mathrm{H}_{2} \mathrm{O}_{2}$} & \multirow{3}{*}{$\begin{array}{l}\text { CV, } \\
\%\end{array}$} & \multirow{3}{*}{ Producer } \\
\hline & \multicolumn{2}{|c|}{ Estimated } & \multirow{2}{*}{$\begin{array}{l}\text { Declared, } \\
\%\end{array}$} & & \\
\hline & $\mathrm{mM}$ & $\%$ & & & \\
\hline $\begin{array}{l}\text { Antiseptic spray } \\
\text { for arms }\end{array}$ & 33.2 & 0.11 & 0.10 & 10.0 & $\begin{array}{l}\text { Pharmaceutical } \\
\text { factory "Viola", }\end{array}$ \\
\hline $\begin{array}{l}\text { Universal } \\
\text { antiseptic solution }\end{array}$ & 880 & 2.95 & 3.0 & 1.7 & $\begin{array}{l}\text { Zaporizhzhia, } \\
\text { Ukraine }\end{array}$ \\
\hline Famidez-Sanosil & 588.6 & 1.98 & 2.0 & 1.0 & $\begin{array}{c}\text { Ltd Dezomark, } \\
\text { Novoyavorivsk, } \\
\text { Ukraine }\end{array}$ \\
\hline
\end{tabular}

\section{Conclusions}

In the current research, a number of NPs based on transition and noble metals were synthesized by chemical methods and were screened for their ability to decompose hydro- 
gen peroxide in solutions. Structure, size, morphology, composition, catalytic properties, and electrochemical activities of the chosen PO-like NZs were characterized on the electrode. A more detailed study was performed for $\mathrm{Cu} / \mathrm{Ce}^{\mathrm{S}}-\mathrm{NZ}$, which was found to be the most effective mimetic of PO. It was demonstrated that the synthesized $\mathrm{Cu} / \mathrm{Ce}^{\mathrm{S}}-\mathrm{NZ}$ may be successfully used as an artificial PO for sensor analysis of hydrogen peroxide in commercial disinfectant samples.

Supplementary Materials: The following are available online at https://www.mdpi.com/2076 -3417/11/2/777/s1, Figure S1: Characteristics of the several metallic PO-like nanozymes: SEM images at different magnifications (top) and their X-ray spectral characteristics (bottom); Figure S2: Amperometric characteristics of the several NZ-modified electrodes: chronoamperograms (left), dependence of the current response on increasing concentrations of $\mathrm{H}_{2} \mathrm{O}_{2}$ (middle) and calibration graphs (right). Conditions: working potential $-50 \mathrm{mV}$ vs. $\mathrm{Ag} / \mathrm{AgCl}$ (reference electrode), $50 \mathrm{mM}$ NaOAc buffer, $\mathrm{pH} 4.5$ at $23^{\circ} \mathrm{C}$.

Author Contributions: Conceptualization: G.G. and M.N.; methodology: N.S., O.D. and G.G.; investigation: O.D., R.S. and N.S.; resources: M.G.; data curation: G.G.; writing-original draft preparation: G.G., N.S. and O.D.; writing—review and editing: G.G. and M.N.; supervision: M.G.; project administration: G.G.; funding acquisition: M.G. and M.N. All authors have read and agreed to the published version of the manuscript.

Funding: This work was partially funded by NAS of Ukraine (The program "Smart sensor devices of a new generation based on modern materials and technologies"), by the Ministry of Education and Science of Ukraine (Ukrainian-Lithuanian R\&D, project 0120U103398), by National Research Foundation of Ukraine (project 48/02.2020 "Development of new nanozymes as catalytic elements for enzymatic kits and chemo/biosensors") and by the Research Authority of the Ariel University, Israel.

Institutional Review Board Statement: “Not applicable” for studies not involving humans.

Informed Consent Statement: "Not applicable" for studies not involving humans.

Data Availability Statement: “Not applicable” for studies not involving humans.

Acknowledgments: We acknowledge Mariya F. Ivash (Institute of Cell Biology, Lviv, Ukraine) for technical support and experimental assistance.

Conflicts of Interest: The authors declare no conflict of interest.

\section{Abbreviations}

\begin{tabular}{|c|c|}
\hline $2,4-\mathrm{DCP}$ & 2,4-Dichlorophenol \\
\hline ABTS & 2,2'-Azinobis-(3-ethylbenzthiazoline-6-sulphonate) \\
\hline CV & Cyclic voltammetry \\
\hline DBD & Diamond boron-doped \\
\hline $\mathrm{gCuHCF}$ & Hexacyanoferrate of coppers obtained via enzyme \\
\hline GCE & Glassy carbon electrode \\
\hline GE & Graphite electrode \\
\hline HNCs & Hollow nanocubes \\
\hline$I_{\max }$ & Maximal current response on tested analyte at substrate saturation \\
\hline$K_{M}^{a p p}$ & Apparent Michaelis-Menten constant \\
\hline LOD & Limit of detection \\
\hline LR & Linear range \\
\hline MOFs & Metal-Organic Frameworks \\
\hline NPs & Nanoparticles \\
\hline NZ & Nanozyme \\
\hline $\mathrm{Me} / \mathrm{Ce}^{\mathrm{S}}$ & Nanozyme obtained in the presence of $\mathrm{Na}_{2} \mathrm{~S}$ in reaction mixture; where $\mathrm{Me}-\mathrm{Fe}, \mathrm{Cu}$ or $\mathrm{Ag}$. \\
\hline OPD & $o$-Phenylenediamine \\
\hline $\mathrm{PO}$ & Natural horseradish peroxidase \\
\hline SAT & Standard addition test \\
\hline SEM-XRM & Scanning electron microscopy coupled with X-ray microanalysis \\
\hline TMB & $3,5,3^{\prime}, 5^{\prime}$-Tetramethylbenzidine \\
\hline
\end{tabular}




\section{References}

1. Dunford, H.B. Heme Peroxidases (University of Alberta); Wiley-VCH, John Wiley and Sons: New York, NY, USA, 1999; 507p, ISBN 0-471-24244-6.

2. Veitch, N.C.; Smith, A.T. Horseradish peroxidase. Comput. Chem. 2000, 51, 107-162. [CrossRef]

3. Plieth, C. Peroxide-Induced Liberation of Iron from Heme Switches Catalysis during Luminol Reaction and Causes Loss of Light and Heterodyning of Luminescence Kinetics. ACS Omega 2019, 4, 3268-3279. [CrossRef] [PubMed]

4. Tatsuma, T.; Watanabe, T. Peroxidase model electrodes: Heme peptide modified electrodes as reagentless sensors for hydrogen peroxide. Anal. Chem. 1991, 63, 1580-1585. [CrossRef] [PubMed]

5. Neumann, B.; Wollenberger, U. Electrochemical Biosensors Employing Natural and Artificial Heme Peroxidases on Semiconductors. Sensors 2020, 20, 3692. [CrossRef]

6. Attar, F.; Shahpar, M.G.; Rasti, B.; Sharifi, M.; Saboury, A.A.; Rezayat, S.M.; Falahati, M. Nanozymes with intrinsic peroxidase-like activities. J. Mol. Liq. 2019, 278, 130-144. [CrossRef]

7. Wu, J.; Wang, X.; Wang, Q.; Lou, Z.; Li, S.; Zhu, Y.; Qin, L.; Wei, H. Nanomaterials with enzyme-like characteristics (nanozymes): Next-generation artificial enzymes (II). Chem. Soc. Rev. 2019, 48, 1004-1076. [CrossRef]

8. Gallay, P.; Eguílaz, M.; Rivas, G.A. Designing electrochemical interfaces based on nanohybrids of avidin functionalized-carbon nanotubes and ruthenium nanoparticles as peroxidase-like nanozyme with supramolecular recognition properties for site-specific anchoring of biotinylated residues. Biosens. Bioelectron. 2020, 148, 111764. [CrossRef]

9. Sun, L.; Ding, Y.; Jiang, Y.; Liu, Q. Montmorillonite-loaded ceria nanocomposites with superior peroxidase-like activity for rapid colorimetric detection of $\mathrm{H}_{2} \mathrm{O}_{2}$. Sens. Actuators B Chem. 2017, 239, 848-856. [CrossRef]

10. Cui, F.; Deng, Q.; Sun, L. Prussian blue modified metal-organic framework MIL-101(Fe) with intrinsic peroxidase-like catalytic activity as a colorimetric biosensing platform. RSC Adv. 2015, 5, 98215-98221. [CrossRef]

11. Komkova, M.A.; Pasquarelli, A.; Andreev, E.A.; Galushin, A.A.; Karyakin, A.A. Prussian Blue modified boron-doped dia-mond interfaces for advanced $\mathrm{H}_{2} \mathrm{O}_{2}$ electrochemical sensors. Electrochim. Acta 2020, 339, 135924. [CrossRef]

12. Stasyuk, N.; Smutok, O.; Demkiv, O.M.; Prokopiv, T.; Gayda, G.Z.; Nisnevitch, M.; Gonchar, M.V. Synthesis, Catalytic Properties and Application in Biosensorics of Nanozymes and Electronanocatalysts: A Review. Sensors 2020, 20, 4509. [CrossRef] [PubMed]

13. Qin, L.; Hu, Y.; Wei, H. Nanozymes: Preparation and Characterization. In Nanotechnology for Electronics, Photonics, and Renewable Energy; Springer Science and Business Media LLC: Berlin/Heidelberg, Germany, 2020; pp. 79-101.

14. Yue, Y.; Wei, H.; Guo, J.; Yang, Y. Ceria-based peroxidase-mimicking nanozyme with enhanced activity: A coordination chemistry strategy. Colloids Surf. A Physicochem. Eng. Asp. 2021, 610, 125715. [CrossRef]

15. Wang, Z.; Zhang, R.; Yan, X.; Fan, K. Structure and activity of nanozymes: Inspirations for de novo design of nanozymes. Mater. Today 2020, 41, 81-119. [CrossRef]

16. Wang, Y.; Mao, J.; Meng, X.; Yu, L.; Deng, D.; Bao, X. Catalysis with Two-Dimensional Materials Confining Single Atoms: Concept, Design, and Applications. Chem. Rev. 2019, 119, 1806-1854. [CrossRef]

17. Shen, J.; Shafiq, M.; Ma, M.; Chen, H. Synthesis and Surface Engineering of Inorganic Nanomaterials Based on Microfluidic Technology. Nanomaterials 2020, 10, 1177. [CrossRef]

18. Huang, Y.; Ren, J.; Qu, X. Nanozymes: Classification, Catalytic Mechanisms, Activity Regulation, and Applications. Chem. Rev. 2019, 119, 4357-4412. [CrossRef]

19. Chen, J.; Qiu, H.; Zhao, S. Fabrication of chemiluminescence resonance energy transfer platform based on nanomaterial and its application in optical sensing, biological imaging and photodynamic therapy. TrAC Trends Anal. Chem. 2020, 122, 115747. [CrossRef]

20. Rauf, S.; Ali, N.; Tayyab, Z.; Shah, M.A.K.Y.; Yang, C.P.; Hu, J.; Kong, W.; Huang, Q.; Hayat, A.; Muhammad, N. Ionic liquid coated zerovalent manganese nanoparticles with stabilized and enhanced peroxidase-like catalytic activity for colorimetric detection of hydrogen peroxide. Mater. Res. Express 2020, 7, 035018. [CrossRef]

21. Zhang, K.; Zuo, W.; Wang, Z.; Liu, J.; Li, T.; Wang, B.; Yang, Z. A simple route to CoFe2O4 nanoparticles with shape and size control and their tunable peroxidase-like activity. RSC Adv. 2015, 5, 10632-10640. [CrossRef]

22. Liu, B.; Liu, J. Surface modification of nanozymes. Nano Res. 2017, 10, 1125-1148. [CrossRef]

23. Zhao, M.; Huang, J.; Zhou, Y.; Pan, X.; Chen, Z.; Ye, Z.; Pan, X. Controlled synthesis of spinel $\mathrm{ZnFe}_{2} \mathrm{O}_{4}$ decorated $\mathrm{ZnO}$ heterostructures as peroxidase mimetics for enhanced colorimetric biosensing. Chem. Commun. 2013, 49, 7656-7658. [CrossRef] [PubMed]

24. Liu, C.; Yan, Y.; Zhang, X.; Mao, Y.; Ren, X.; Hu, C.; He, W.; Yin, J.-J. Regulating the pro- and anti-oxidant capabilities of bimetallic nanozymes for the detection of Fe2+ and protection of Monascus pigments. Nanoscale 2020, 12, 3068-3075. [CrossRef] [PubMed]

25. Liu, M.; Kong, L.; Wang, X.; He, J.; Bu, X.-H. Engineering Bimetal Synergistic Electrocatalysts Based on Metal-Organic Frameworks for Efficient Oxygen Evolution. Small 2019, 15, e1903410. [CrossRef] [PubMed]

26. Cao-Milán, R.; He, L.D.; Shorkey, S.; Tonga, G.Y.; Wang, L.-S.; Zhang, X.; Uddin, I.; Das, R.; Sulak, M.; Rotello, V.M. Modulating the catalytic activity of enzyme-like nanoparticles through their surface functionalization. Mol. Syst. Des. Eng. 2017, 2, 624-628. [CrossRef]

27. Wang, X.; Hu, Y.; Wei, H. Nanozymes in bionanotechnology: From sensing to therapeutics and beyond. Inorg. Chem. Front 2016, 3, 41-60. [CrossRef] 
28. Chen, J.; Wei, X.; Tang, H.; Munyemana, J.C.; Guan, M.; Zhang, S.; Qiu, H. Deep eutectic solvents-assisted synthesis of ZnCo $2 \mathrm{O}_{4}$ nanosheets as peroxidase-like nanozyme and its application in colorimetric logic gate. Talanta 2021, 222, 121680. [CrossRef]

29. Rane, A.V.; Kanny, K.; Abitha, V.K.; Sabu, T. Chapter 5. Methods for Synthesis of Nanoparticles and Fabrication of Nanocomposites. In Synthesis of Inorganic Nanomaterials Advances and Key Technologies Micro and Nano Technologies, 1st ed.; Bhagyaraj, S.M., Oluwafemi, O.S., Kalarikkal, N., Sabu, T., Eds.; Woodhead Publishing Company: Sawston, UK, 2018; pp. 121-139. ISBN 9780081019757.

30. Suriati, G.; Mariatti, M.; Azizan, A. Synthesis of silver nanoparticles bu chemical reduction method: Effect of reducing agent and surfactant concentration. Int. J. Automot. Mech. Eng. 2014, 10, 1920-1927. [CrossRef]

31. Chen, H.-I.; Chang, H.-Y. Synthesis of nanocrystalline cerium oxide particles by the precipitation method. Ceram. Int. 2005, 31, 795-802. [CrossRef]

32. Vokhmyanina, D.V.; Andreeva, K.D.; Komkova, M.A.; Karyakina, E.E.; Karyakin, A.A. 'Artificial peroxidase' nanozyme-enzyme based lactate biosensor. Talanta 2020, 208, 120393. [CrossRef]

33. Neampet, S.; Ruecha, N.; Qin, J.; Wonsawat, W.; Chailapakul, O.; Rodthongkum, N. A nanocomposite prepared from platinum particles, polyaniline and a Ti3C2 MXene for amperometric sensing of hydrogen peroxide and lactate. Microchim. Acta 2019, 186, 752. [CrossRef]

34. Matos-Peralta, Y.; Antuch, M. Review-Prussian Blue and Its Analogs as Appealing Materials for Electrochemical Sensing and Biosensing. J. Electrochem. Soc. 2019, 167, 037510. [CrossRef]

35. Meng, X.; Gao, L.; Fan, K.; Yan, X. Nanozyme-Based Tumor Theranostics; Springer Science and Business Media LLC: Berlin/Heidelberg, Germany, 2020; pp. 425-457.

36. Chen, W.; Gao, G.; Jin, Y.; Deng, C. A facile biosensor for A $\beta 40 \mathrm{O}$ based on fluorescence quenching of prussian blue nanoparticles. Talanta 2020, 216, 120930. [CrossRef] [PubMed]

37. He, L.; Li, Z.; Guo, C.; Hu, B.; Wang, M.; Du, M.; Du, M. Bifunctional bioplatform based on NiCo Prussian blue analogue: Label-free impedimetric aptasensor for the early detection of carcino-embryonic antigen and living cancer cells. Sens. Actuators $B$ Chem. 2019, 298, 126852. [CrossRef]

38. Tabrizi, M.A.; Shamsipur, M.; Saber, R.; Sarkar, S.; Zolfaghari, N. An ultrasensitive sandwich-type electrochemical immunosensor for the determination of SKBR-3 breast cancer cell using rGO-TPA/FeHCFnano labeled Anti-HCT as a signal tag. Sens. Actuators B Chem. 2017, 243, 823-830. [CrossRef]

39. Jiang, D.; Ni, D.; Rosenkrans, Z.T.; Huang, P.; Yan, X.; Cai, W. Nanozyme: New horizons for responsive biomedical applications. Chem. Soc. Rev. 2019, 48, 3683-3704. [CrossRef]

40. Wang, P.; Wang, T.; Hong, J.; Yan, X.; Liang, M. Nanozymes: A New Disease Imaging Strategy. Front. Bioeng. Biotechnol. 2020, 8 , 15. [CrossRef]

41. Stasyuk, N.; Gayda, G.Z.; Zakalskiy, A.E.; Zakalska, O.; Serkiz, R.; Gonchar, M. Amperometric biosensors based on oxidases and PtRu nanoparticles as artificial peroxidase. Food Chem. 2019, 285, 213-220. [CrossRef]

42. Gayda, G.Z.; Demkiv, O.M.; Gurianov, Y.; Serkiz, R.Y.; Gonchar, M.V.; Nisnevitch, M. “Green” Nanozymes: Synthesis, Characterization, and Application in Amperometric (Bio)sensors. Multidiscip. Digit. Publ. Inst. Proc. 2020, 60, 58. [CrossRef]

43. Gayda, G.Z.; Demkiv, O.M.; Stasyuk, N.Y.; Serkiz, R.Y.; Lootsik, M.D.; Errachid, A.; Gonchar, M.V.; Nisnevitch, M. Metallic Nanoparticles Obtained via "Green" Synthesis as a Platform for Biosensor Construction. Appl. Sci. 2019, 9, 720. [CrossRef]

44. Stasyuk, N.; Gayda, G.Z.; Klepach, H.; Gonchar, M.V. Nanoparticles of Noble Metals as Effective Platforms for the Fabrication of Amperometric Biosensors on Hydrogen Peroxide. Sens. Lett. 2016, 14, 1169-1177. [CrossRef]

45. Liu, J.; Yang, C.; Shang, Y.; Zhang, P.; Liu, J.; Zheng, J. Preparation of a nanocomposite material consisting of cuprous oxide, polyaniline and reduced graphene oxide, and its application to the electrochemical determination of hydrogen peroxide. Microchim. Acta 2018, 185, 172. [CrossRef] [PubMed]

46. Zhao, Y.; Huo, D.; Bao, J.; Yang, M.; Chen, M.; Hou, J.; Fa, H.; Hou, C. Biosensor based on 3D graphene-supported Fe $\mathrm{O}_{4}$ quantum dots as biomimetic enzyme for in situ detection of $\mathrm{H} 2 \mathrm{O} 2$ released from living cells. Sens. Actuators B Chem. 2017, 244, 1037-1044. [CrossRef]

47. Niu, Q.; Bao, C.; Cao, X.; Liu, C.; Wang, H.; Lu, W. Ni-Fe PBA hollow nanocubes as efficient electrode materials for highly sensitive detection of guanine and hydrogen peroxide in human whole saliva. Biosens. Bioelectron. 2019, 141, 111445. [CrossRef] [PubMed]

48. Keihan, A.H.; Karimi, R.R.; Sajjadi, S. Wide dynamic range and ultrasensitive detection of hydrogen peroxide based on beneficial role of gold nanoparticles on the electrochemical properties of prussian blue. J. Electroanal. Chem. 2020, 862, 114001. [CrossRef]

49. Pang, H.; Zhang, Y.; Cheng, T.; Lai, W.-Y.; Huang, W. Uniform manganese hexacyanoferrate hydrate nanocubes featuring superior performance for low-cost supercapacitors and nonenzymatic electrochemical sensors. Nanoscale 2015, 7, 16012-16019. [CrossRef]

50. Zhang, C.; Zhang, Y.; Du, X.; Chen, Y.; Dong, W.; Han, B.; Chen, Q. Facile fabrication of Pt-Ag bimetallic nanoparticles decorated reduced graphene oxide for highly sensitive non-enzymatic hydrogen peroxide sensing. Talanta 2016, 159, 280-286. [CrossRef]

51. Sitnikova, N.A.; Borisova, A.V.; Komkova, M.A.; Karyakin, A.A. Superstable Advanced Hydrogen Peroxide Transducer Based on Transition Metal Hexacyanoferrates. Anal. Chem. 2011, 83, 2359-2363. [CrossRef]

52. Pandey, P.C.; Panday, D.; Pandey, A.K. Polyethylenimine mediated synthesis of copper-iron and nickel-iron hexacyanoferrate nanoparticles and their electroanalytical applications. J. Electroanal. Chem. 2016, 780, 90-102. [CrossRef] 
53. Karpova, E.V.; Karyakina, E.E.; Karyakin, A.A. Communication-Accessing Stability of Oxidase-Based Biosensors via Stabilizing the Advanced H2O2Transducer. J. Electrochem. Soc. 2017, 164, B3056-B3058. [CrossRef]

54. Zhou, L.; Wu, S.; Xu, H.; Zhao, Q.; Zhang, Z.; Yao, Y. Preparation of poly(N-acetylaniline)-Prussian blue hybrid composite film and its application to hydrogen peroxide sensing. Anal. Methods 2014, 6, 8003-8010. [CrossRef]

55. Karyakin, A.A.; Karyakina, E.E.; Gorton, L. Amperometric Biosensor for Glutamate Using Prussian Blue-Based "Artificial Peroxidase" as a Transducer for Hydrogen Peroxide. Anal. Chem. 2000, 72, 1720-1723. [CrossRef] [PubMed]

56. Zhang, Y.; Duan, Y.; Shao, Z.; Chen, C.; Yang, M.; Lu, G.; Xu, W.; Liao, X. Amperometric hydrogen peroxide sensor using a glassy carbon electrode modified with a nanocomposite prepared from ferumoxytol and reduced graphene oxide decorated with platinum nanoparticles. Microchim. Acta 2019, 186, 386. [CrossRef] [PubMed]

57. Karyakin, A.A.; Gitelmacher, O.V.; Karyakina, E.E. Prussian Blue-Based First-Generation Biosensor. A Sensitive Am-perometric Electrode for Glucose. Anal. Chem. 1995, 67, 2419-2423. [CrossRef] 